\title{
OCCUPATIONAL EXPOSURE TO NANOPARTICLES ORIGINATING FROM WELDING - CASE STUDIES FROM THE CZECH REPUBLIC
}

\author{
Filip Berger, Šárka Bernatíková, Lucie Kocůrková, Radka Přichystalová, Lenka Schreiberová \\ VSB - Technical University of Ostrava, Ostrava, Czech Republic \\ Faculty of Safety Engineering
}

\begin{abstract}
Background: Nanomaterials are virtually ubiquitous as they are created by both natural processes and human activities. The amount of occupational exposure to unintentionally released nanoparticles can, therefore, be substantial. The aim of the study was to determine the concentrations of incidental nanoparticles that workers can be exposed to during welding operations and to assess related health risks. The specific focus on welding operations was determined based on the fact that other case studies on the manufacturing industry confirm significant exposure to incidental nanoparticles during welding. In the Czech Republic, 92\% of all industrial workers are employed in the manufacturing industry, where welding operations are amply represented. Material and Methods: The particle number concentrations of particles in the size range of 20-1000 nm and particle mass concentrations of inhalable and $\mathrm{PM}_{1}$ fractions were determined via measurements carried out at 15-minute intervals for each welding operation by static sampling in close proximity to the worker. Measurements were obtained using the following instruments: NanoScan SMPS 3910, Optical Particle Sizer OPS 3330, P-TRAK 8525 and DustTrak DRX 8534. The assessed operations were manual arc welding and automatic welding. Results: The observed average particle number concentrations for electric arc welders ranged $84 \times 10^{3}-176 \times 10^{3} \# / \mathrm{cm}^{3}$, for welding machine operators $96 \times 10^{3}-147 \times 10^{3} \# / \mathrm{cm}^{3}$, and for a welding locksmith the obtained average concentration was $179 \times 10^{3} \# / \mathrm{cm}^{3}$. The determined average mass concentration of $\mathrm{PM}_{1}$ particles ranged $0.45-1.4 \mathrm{mg} / \mathrm{m}^{3}$. Conclusions: Based on the conducted measurements, it was confirmed that there is a significant number of incidental nanoparticles released during welding operations in the manufacturing industry as a part of production and processing of metal products. The recommended occupational exposure limits for nanoparticle number concentrations were exceeded approximately 4-8 times for all assessed welding operations. The use of local exhaust ventilation in conjunction with personal protective equipment, including FFP2 or FFP3 particle filters, for welding is, therefore, recommended. Med Pr. 2021;72(3):219-30
\end{abstract}

Key words: aerosol, nanomaterials, nanoparticles, occupational exposure, occupational exposure limit, welding

Corresponding author: Filip Berger, VSB - Technical University of Ostrava, Faculty of Safety Engineering, Lumírova 630/13, 70030 Ostrava-Výškovice, Czech Republic, e-mail: filip.berger@vsb.cz

Received: August 31, 2020, accepted: January 13, 2021

\section{INTRODUCTION}

The nanomaterial sector has been developing at an enormous rate since the second half of the 20th century. Nanomaterials have been applied mainly in the consumer, food and pharmaceutical industries. The use of nanomaterials naturally causes exposure of both workers producing nanomaterials and consumers using products containing them. Studies have already substantiated the harmfulness of specific nanomaterials to living organisms, which has prompted various institutions, such as the European Commission, the Organization for Economic Co-operation and Development, and the International Organization for Standardization, to regulate the sector based on the precautionary principle [1-3].

Attention is focused on the delimitation of nanomaterials and their targeted use, e.g., in agriculture or the food industry $[4,5]$. The obligations of manufacturers and importers of products containing nanomaterials arising from the existing regulation include mainly product registration, authorization, determination of risks, and the use of appropriate risk assessment methods, as well as labeling such products with the term "nano" [6]. However, food and agriculture are only the most obvious examples of exposure. In fact, 
exposure to nanomaterials is a matter of everyday life and can occur, e.g., when traveling by public transport, staying in environments with smoke, or using fireworks [7]. Nanomaterials are, therefore, an integral part of the air we breathe.

Anthropogenic nanomaterials are created by human activities. They are divided into 2 subcategories. Nanomaterials manufactured intentionally are called engineered nanomaterials [8]. This category includes, e.g., nano alumina $\left(\mathrm{Al}_{2} \mathrm{O}_{3}\right)$ often used in cosmetic products for small-sized particles and optical properties, titanium dioxide $\left(\mathrm{TiO}_{2}\right)$ used as color pigment for high brightness, silver nanoparticles which are known for their antibacterial effects, and fullerenes used for mechanical properties [1]. Nanomaterials formed as an unwanted by-product of human activities are called incidental nanomaterials/nanoparticles [8]. Incidental nanoparticles can occur at workplaces during activities that are unrelated to their targeted production like machining and welding [9]. Thus, nanoparticles contribute to the overall pollution of the working environment and may increase the health risks associated with inhalation exposure to aerosols. The term "ultrafine particles" (UFPs) is commonly associated with incidental nanoparticles. It is generally accepted that UFPs have dimensions up to $100 \mathrm{~nm}$. Nevertheless, as regards their further specification, scientific literature begins to diverge; this term is frequently used in the same meaning as incidental nanoparticles or to denote all naturally occurring nanoparticles, depending on the source literature $[8,10]$.

Nanoparticles that can occur in the working environment include the following: metal nanoparticles, carbon black, nanoparticles from materials used and produced during ceramic sintering (clay, kaolin, iron and silicon oxides, ceramics, porcelain) colored pigments (metal oxides), gypsum, cements, combustion emissions, particles released during paper manufacturing, wood and plastic nanoparticles, spray mixtures containing $\mathrm{ZnO}$, composite materials (containing epoxy resin, 'nano' component, glass and carbon fibers), mixtures with nano-constituents such as $\mathrm{TiO}_{2}, \mathrm{SiO}_{2}$, $\mathrm{Al}_{2} \mathrm{O}_{3}$, and carbon nanotubes [9,11-18]. The most common working activities that may accidentally release nanoparticles are machining (milling, turning, drilling, grinding, cutting), arc welding, spraying, surface treatment application, combustion processes, bulk material handling (mixing, packaging), melting and casting of metals $[7,9,11,13,16,19]$.

Neither nanoparticle sources nor working activities can be assessed independently of each other.
The amount of released nanoparticles always depends on the specific combination of the nanoparticle source (material) and the work activity. In the case of woodworking, the amount of released nanoparticles and their shape depends on the type of wood (teak, massarandu$\mathrm{ba}$, etc.) and the processing operation (drilling, milling, grinding) [20].

Health risks arising from exposure to nanoparticles are currently demonstrated by toxicological studies pointing out the toxicity of specific nanoparticles. The regulation is mainly aimed at engineered nanoparticles and products which contain them. Nevertheless, attention should also be paid to those nanoparticles that enter the atmosphere during, or as a co-product of, daily work. The number of people exposed to engineered nanoparticles during their production is relatively small compared to the number of people exposed to incidental nanoparticles. In these cases, regulation is mostly based on the recommended occupational exposure limits (OELs). The specific focus of this study on welding operations was determined based on a review of published exposure case studies on individual branches of the manufacturing industry, where increased exposure to incidental nanoparticles during welding is described $[7,9,11]$. Furthermore, welding operations are a common part of production in companies engaged in the manufacture and machining of metal structures, products and machinery. Thus, the aim of the study was to determine both the concentrations and particle number size distributions of incidental nanoparticles at welding workplaces and to assess related risks.

The narrower focus of the study on welding operations comes from the fact that case studies on the manufacturing industry confirm the increased exposure to incidental nanoparticles during welding [9]. In the Czech Republic, 92\% of all industrial workers are employed in the manufacturing industry, where welding operations are amply represented [21,22]. In addition, the number of people exposed to engineered nanoparticles during targeted production is relatively small compared to the number of people exposed to incidental nanoparticles [9].

\section{MATERIAL AND METHODS}

With regard to the preliminary literature review of exposure studies to incidental nanoparticles in the manufacturing industry, which was conducted by the authors, specific companies in the Czech Republic with expected incidental nanoparticle exposure had been identified and 
contacted via e-mail, telephone and in person [9,11-20]. Subsequently, a field survey was carried out. The field survey consisted of a semi-structured questionnaire designated for companies on the basis of which specific job positions and working operations were selected. The semi-structured questionnaire included 40 questions concerning general information (company name, industry classification - NACE, number of employees), the exposure scenario (multiple choice items with brief descriptions of selected scenarios), the characteristics of processed/used material (chemical composition, state of matter, quantity), exposure details (number of exposed workers, length of exposure, shift system, worker's distance from a nanomaterial source), workplace information (dimensions, ventilation system), waste disposal and established risk controls. For the purposes of this study, only welding operations (manual or partially automated) were selected.

The presented results contain measurements conducted in the first half of 2019 in 3 companies engaged in the manufacture and machining of metal structures, fabricated metal products, machinery and equipment or motor vehicle components. All these companies are based in the Czech Republic, in the Moravian-Silesian Region. According to the NACE classification of economic activities, all 3 enterprises are classified to section C - manufacturing, division 25 - manufacture of fabricated metal products, except machinery and equipment. Overall, 8 work operations concerning electric arc welding were assessed. These operations were done daily as a main activity during an entire shift. One exposure measurement was conducted for each presented welding operation. In total, exposure of 8 workers (engaged in welding operations) was determined. More specifically, 2 workers (engaged in welding operations) were from company A, 4 workers from company $\mathrm{B}$, and 2 workers from company $\mathrm{C}$. The majority of workers were males apart from an operator of a type A welding machine (WO4) and a spot welder (WO6).

The measurements consisted of determining the particle number concentration of particles in the size range of $20-1000 \mathrm{~nm} / \mathrm{cm}^{3}$ of air, and the particle number size distribution of particles in the size range of $10-10000 \mathrm{~nm} / \mathrm{cm}^{3}$ of air. The particle mass concentrations of size fractions $\mathrm{PM}_{1}, \mathrm{PM}_{25}, \mathrm{PM}_{4}$ (respirable fractions), $\mathrm{PM}_{10}$ and the total (inhalable) fraction were measured along with particle number concentrations. The measurements were carried out using on-line measuring instruments, which record measured values in real time. The P-TRAK 8525 portable particle counter
(TSI, Shoreview, USA) with the size range of $0.02-1 \mu \mathrm{m}$ was used to determine the particle number concentration, and the DustTrak DRX 8534 portable particle counter (TSI, Shoreview, USA) with the size range of 0.1-15 $\mu \mathrm{m}$ was employed to determine the particle mass concentration of the aforementioned PM size fractions.

Furthermore, the NanoScan SMPS 3910 Mobility Scanner (TSI, Shoreview, USA) with 13 size channels was used to determine the particle number size distribution in the overall size range of $10-350 \mathrm{~nm}$, and the Optical Particle Sizer OPS 3330 with 16 size channels was used to determine the particle number size distribution in the overall size range of $0.3-10 \mu \mathrm{m}$. Using specialized software (Multi-Instrument Manager ${ }^{\mathrm{TM}}$, TSI, Shoreview, USA), the particle number size distributions in the size range of $10-10000 \mathrm{~nm}$ were obtained by combining the NanoScan SMPS 3910 and OPS 3330 instrument data. The instruments were calibrated by the manufacturer. The flow check and zero calibrations using the HEPA filter were performed before each measurement. The microclimatic conditions during each measurement were recorded as well. The detailed specification of all used measuring instruments is given in Table 1.

The measurements were taken in accordance with valid standards $[23,24]$. Static sampling was performed at 15-minute intervals for each welding operation in close proximity to the worker in order to measure personal exposure. Details regarding distances between measuring instruments and the aerosol source/worker's breathing zone can be found in Table 2. Additionally, background concentration level measurements were performed during work breaks. Data acquired from measuring instruments were processed using TrakPro ${ }^{\mathrm{TM}}$ Data Analysis Software (TSI, Shoreview, USA) and Microsoft Excel (Microsoft Corporation, USA).

\section{RESULTS}

The descriptions of companies, welding operations and obtained particle number and mass concentration values are given in the following subsections.

\section{Company A}

Company $\mathrm{A}$ is engaged in the custom manufacturing and maintenance of machine components. The characteristic work processes are metalworking and welding. The company is a medium-sized enterprise (50-250 employees). Work is done 5 days a week. The production premises are divided into 2 mutually separated 
Table 1. Specification of measuring instruments

\begin{tabular}{|c|c|c|c|}
\hline Measuring instrument & Measured value and output & Aerosol concentration range & Particle size range \\
\hline P-TRAK 8525 (TSI) & particle number concentration & $1-10^{5}$ particles $/ \mathrm{cm}^{3}$ & $0.02-1 \mu \mathrm{m}$ \\
\hline DustTrak DRX 8534 (TSI) & $\begin{array}{l}\text { particle mass concentration }-\mathrm{PM}_{1} \text {, } \\
\mathrm{PM}_{2.5}, \mathrm{PM}_{4}, \mathrm{PM}_{10} \text { and total fraction }\end{array}$ & $0.001-150 \mathrm{mg} / \mathrm{m}^{3}$ & $0.1-15 \mu \mathrm{m}$ \\
\hline NanoScan SMPS 3910 (TSI) & $\begin{array}{l}\text { particle number concentration, } \\
\text { particle size distribution, } \\
13 \text { size channels }\end{array}$ & $1-10^{6}$ particles $/ \mathrm{cm}^{3}$ & $10-350 \mathrm{~nm}$ \\
\hline OPS 3330 (TSI) & $\begin{array}{l}\text { particle number concentration } \\
\text { and particle size distribution, } \\
16 \text { size channels }\end{array}$ & $1-3000$ particles $/ \mathrm{cm}^{3}$ & $0.3-10 \mu \mathrm{m}$ \\
\hline Defender 510M Flow Meter \& Calibrator (Mesa Labs) & flow rate & $50-5000 \mathrm{ml} / \mathrm{min}$ & \\
\hline Hygro-/Thermo-/Barometer & $\begin{array}{l}\text { temperature, atmospheric pressure } \\
\text { and relative humidity }\end{array}$ & $\begin{array}{l}\text { temperature: }-25.0-70.0^{\circ} \mathrm{C} \\
\text { relative humidity: } 0.0-100.0 \%\end{array}$ & \\
\hline Anemometer GREISINGER TA 88 N (GREISINGER) & air velocity & $\begin{array}{l}0.1-15 \mathrm{~m} / \mathrm{s} \\
\text { spread: } 0.01 \mathrm{~m} / \mathrm{s}\end{array}$ & \\
\hline
\end{tabular}

halls. The described welding operations took place in a hall with a total volume of $>1000 \mathrm{~m}^{3}$, in which usually 10 employees - welders and locksmiths - work on the shift. The first half of the hall is made up of rooms for working on large machine parts and storage space. There are 5 welding areas in the second half of the hall separated by welding screens, each area equipped with local exhaust ventilation. Locksmith welding tables are situated opposite the welding areas. A simplified workplace plan of the hall is shown in Figure 1a.

The hall is equipped with an automatic ventilation system. Air extraction is provided by air intake vents at a height of approximately $3 \mathrm{~m}$, whereby fresh air is supplied through a series of casement windows. The cleaning of each working area is performed by the staff before the end of each shift, and a specialized external company performs general cleaning once a week. Motorized forklift trucks, overhead cranes and other lifting equipment are used in the hall. The background concentration values were measured during a work break. The microclimatic conditions at the workplace during the measurements were as follows: temperature $17^{\circ} \mathrm{C}$, relative humidity $31 \%$, and air flow $0.0 \mathrm{~m} / \mathrm{s}$. A description of the measured welding operations in company A is presented in Table 2.

\section{Company B}

Company B is engaged in the production of metal components for the automotive industry, namely the production of door frames, dashboard carriers and safety reinforcements. Its main line of business is metalworking and welding of mild and stainless steel. It is a large company with $>250$ employees. Every day about 480 employees and 135 agency workers take turns in working shifts in the hall. Work is done 5 days a week. The production hall with a volume of $>1000 \mathrm{~m}^{3}$ (built-up area of $13138 \mathrm{~m}^{2}$ ) is equipped with metal presses, spot welding machines, welding curtains, various types of welding machines, as well as orbital and angle grinding tables. A simplified workplace plan of the part of the hall where the measurements took place is shown in Figure $1 b$.

The hall is equipped with a mechanical ventilation system. Cleaning takes place during each shift, when a cleaning machine passes through the production hall. Electric forklift trucks are operated in the hall. The background concentration values were measured during a lunch break. The microclimatic conditions at the workplace during the measurements were as follows: temperature $25^{\circ} \mathrm{C}$, relative humidity $43 \%$, and airflow $0.8 \mathrm{~m} / \mathrm{s}$. A description of the measured welding operations in company B is provided in Table 2 .

\section{Company C}

Company $\mathrm{C}$ manufactures boilers. Based on the number of employees, it is a medium-sized enterprise. Work is done 5 days a week. The measured work activities take place in a production hall with a total volume of $>1000 \mathrm{~m}^{3}$, where approximately 45 workers including welders work during the shift. The welder's job consists of metalworking and welding of structural steel. A simplified workplace plan of the hall is shown in Figure 1c.

The hall is equipped with a mechanical ventilation system with 11 air intake vents located at a height of about $4 \mathrm{~m}$. Cleaning is carried out 3 times a week with a floor cleaning machine. The background concentration 
a)

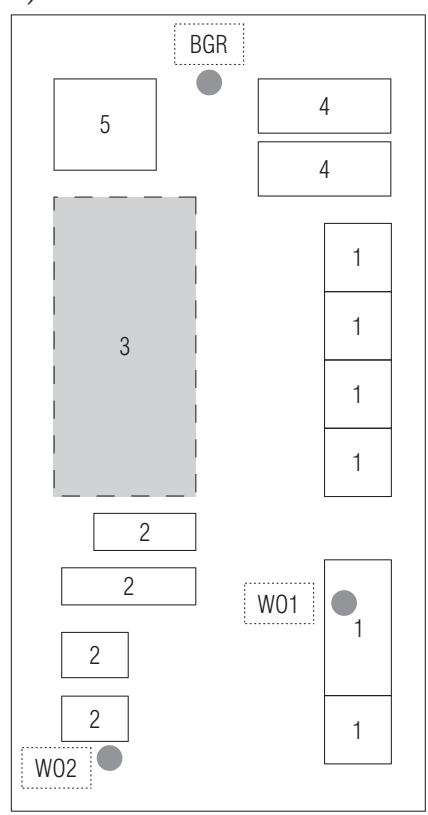

1 - welding areas, 2 - locksmith welding tables, 3 - storage space, 4 - open workplaces for welding large components, 5 - heating furnace.

Measuring locations: BGR - background concentration measurement, WO1 welding operation No. 1, WO2 - welding operation No. 2. b)

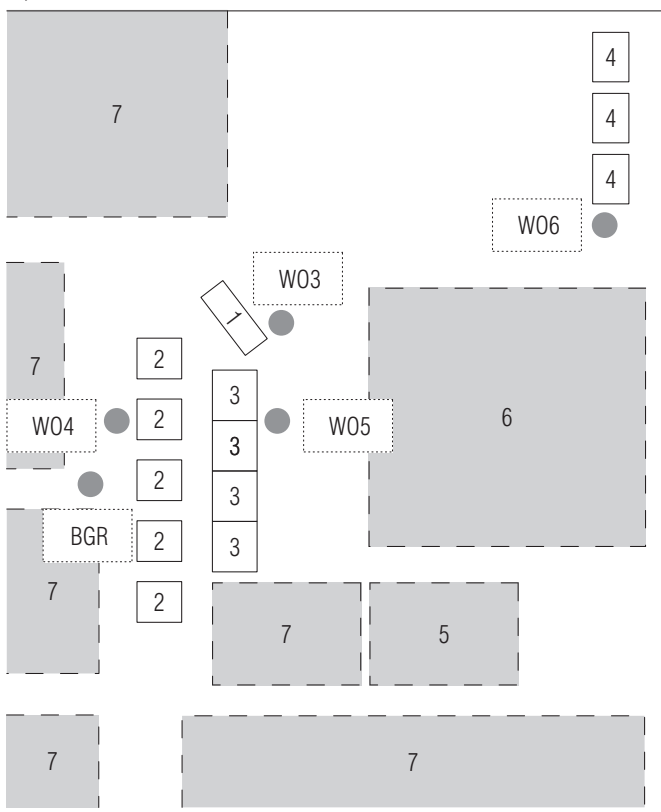

1 - welding table, 2 - type A welding machines, 3 - type B welding machines, 4 - spot welding machines, 5 - grinding and welding workstations, 6 - handling area, 7 - forming and welding workstations.

Measuring locations: BGR - background concentration measurement, WO3 - welding operation No. 3, WO4 - welding operation No. 4, WO5 - welding operation No. 5, WO6 - welding operation No. 6 . c)

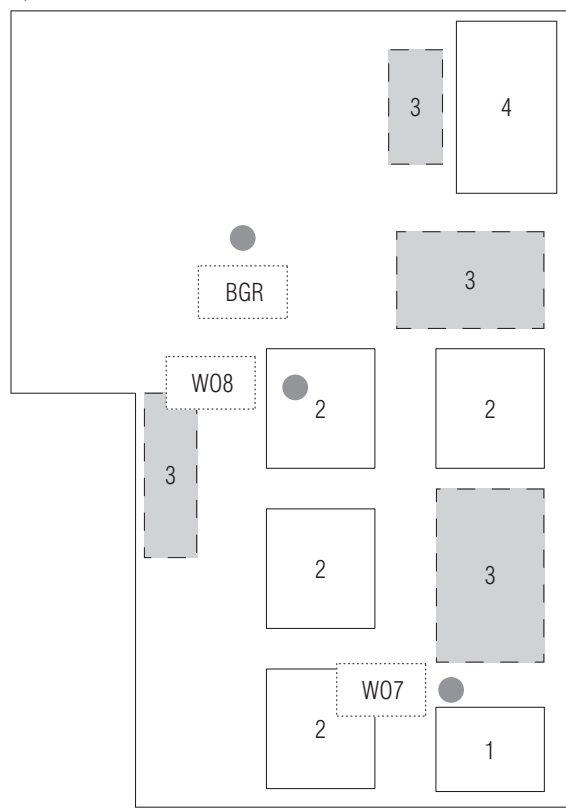

1 - welding areas, 2 - welded steel structures, 3 - storage areas, 4 - burning machine.

Measuring locations: BGR - background concentration measurement, WO7 - welding operation No. 7,

WO8 - welding operation No. 8.

Figure 1. An indicative workplace plan of: a) company A, b) company B, and c) company C, with marked measuring locations

values were measured during a work break. The microclimatic conditions at the workplace during the measurements were as follows: temperature $16^{\circ} \mathrm{C}$, relative humidity $42 \%$, and air flow $0.4 \mathrm{~m} / \mathrm{s}$. A description of the measured welding operations in Company $\mathrm{C}$ is presented in Table 2.

\section{Particle number concentrations}

The measured average particle number concentrations of particles in the size range of $20-1000 \mathrm{~nm}$, presented by enterprise for individual welding operations, are summarized in Table 3 . They are presented together with the values of the average particle number background concentrations and technical risk controls that were in place. The obtained average particle number concentrations ranged $83 \times 10^{3}-179 \times 10^{3} \# / \mathrm{cm}^{3}$, i.e., from 1.6 times (WO7) up to 4 times (WO2) higher than the average background concentration values. The highest average concentration was obtained at $\mathrm{WO} 2$ - Locksmithing. The lowest average concentration was measured during WO7 - MIG/MAG welding III (manual). The obtained values of particle number concentrations were similar apart from WO6 - operation of a spot welding machine and WO7 - MIG/MAG welding III (manual), especially in relation to background concentrations.

The average particle number concentration of all welding operations, excluding the relatively extreme average values of WO6 and WO7, was then

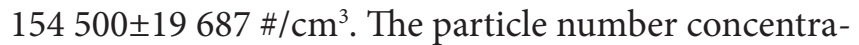
tion of particles in the size range of $20-1000 \mathrm{~nm}$ over time for WO2 - Locksmithing is shown in Figure 2. The combined data from NanoScan SMPS 3910 and OPS 3330 for the particle number size distribution of the particles in the size range of 10-10 $000 \mathrm{~nm}$ for WO2 - Locksmithing are shown in Figure 3.

\section{Particle mass concentrations}

The average obtained particle mass concentrations for the total (inhalable) fraction and the $\mathrm{PM}_{1}$ fraction for individual welding operations, grouped by companies, are summarized in Table 4 . The table also includes the average background concentration values and the implemented technical risk controls. The average total (inhalable) particle mass concentrations of the welding operations ranged $0.546-1.410 \mathrm{mg} / \mathrm{m}^{3}$. The lowest average total particle mass concentration 


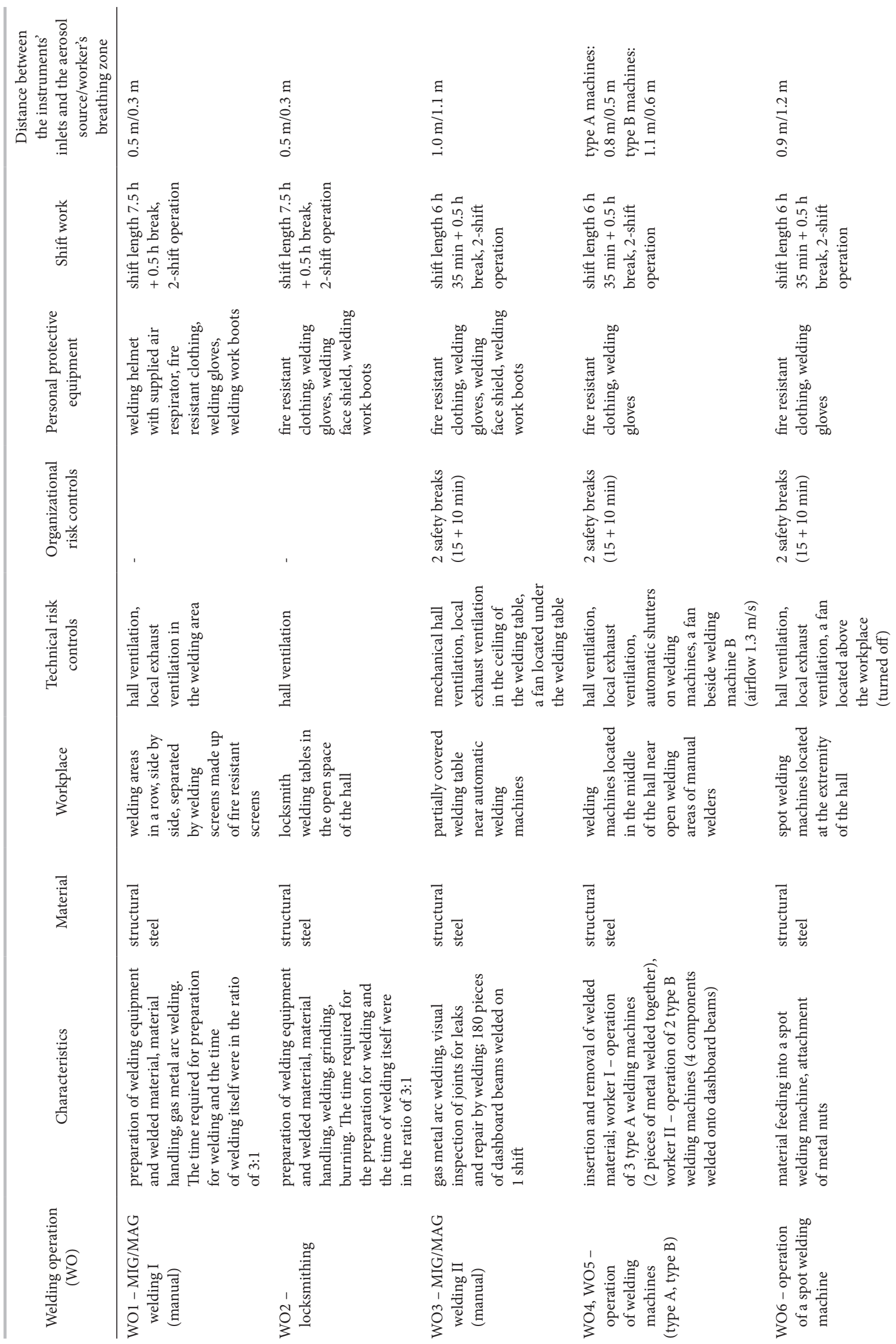




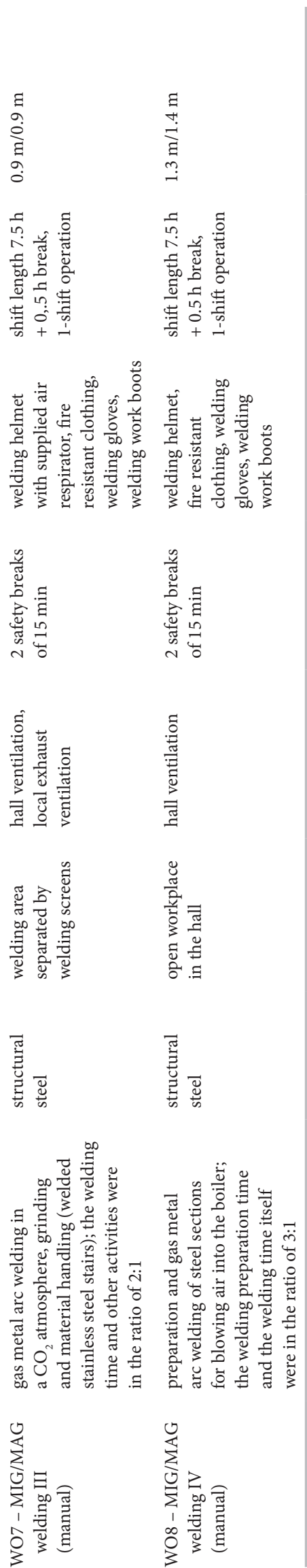

was observed during WO7 - MIG/MAG welding III (manual). The highest average total particle mass concentration was obtained for WO3 - MIG/MAG welding II (manual). The average $\mathrm{PM}_{1}$ concentration ranged $0.453-1.360 \mathrm{mg} / \mathrm{m}^{3}$. The share of the $\mathrm{PM}_{1}$ fraction in the total (inhalable) fraction was between $72-98 \%$, on average $88.5 \pm 8.6 \%$. The highest shares of the $\mathrm{PM}_{1}$ fraction in the total (inhalable) fraction concerned automated welding operations (WO4-WO6).

\section{DISCUSSION}

In this study, various welding operations were measured in order to get further insight into potential exposure of workers to incidental nanoparticles at respective welding workplaces. For the purpose of this study, the measured aerosol characteristics included particle numbers and particle mass concentrations. In the case of nanoparticles, particle number concentrations are more demonstrative than particle mass concentrations, since nanoparticles are characteristic of their low mass. The highest value of the average particle number concentration was present during the work of the welding locksmith (WO2). The high average concentration in the case of WO2 - Locksmithing can be attributed to the absence of local exhaust ventilation and the contribution of particles originating from grinding and burning, which were both parts of the working operation. Electric arc welding accounted for approximately one-third of the locksmith's work. The lowest average particle number concentration was obtained during WO7 - MIG/MAG welding III (manual), despite not having the most technical risk controls in place or the lowest background particle number concentration. The reason for this relatively low average particle number concentration of WO7, in comparison with the other operations, is not apparent.

The relatively high background concentrations in all 3 companies during breaks (43 000-61 $000 \# / \mathrm{cm}^{3}$ ) are also worth mentioning. These concentrations were present in all 3 spatially large $\left(>1000 \mathrm{~m}^{3}\right)$ production halls, where a significant amount of aerosol particles of small sizes was generated as a result of working activities, which could not have been completely ventilated by air conditioning or did not fully deposit over the duration of the breaks. It should be noted that the high ratio of the nanoparticle area and mass, together with a low effect of gravitation, results in longer particle suspension time in the air. Consequently, the particle background concentrations might have been overestimated since the measurements were made during work breaks. 
Table 3. Particle number and mass concentrations

\begin{tabular}{|c|c|c|c|c|c|c|}
\hline \multirow[t]{2}{*}{$\begin{array}{l}\text { Welding operation } \\
\text { (WO) }\end{array}$} & \multicolumn{2}{|c|}{$\begin{array}{c}\text { Average particle number } \\
\text { concentration of particles in } \\
\text { the range of } 20-1000 \mathrm{~nm} \\
{\left[\# / \mathrm{cm}^{3}\right]}\end{array}$} & \multirow[t]{2}{*}{$\begin{array}{l}\text { Technical } \\
\text { risk } \\
\text { controls }\end{array}$} & \multicolumn{2}{|c|}{$\begin{array}{c}\text { Average particle mass } \\
\text { concentration of } \mathrm{PM}_{1} \\
\text { fraction } \\
{\left[\mathrm{mg} / \mathrm{m}^{3}\right]}\end{array}$} & \multirow[t]{2}{*}{$\begin{array}{l}\text { Technical } \\
\text { risk } \\
\text { controls }\end{array}$} \\
\hline & operation & background & & operation & background & \\
\hline Company A & & $61 \times 10^{3}$ & & & 0.554 & \\
\hline WO1 - MIG/MAG welding I (manual) & $134 \times 10^{3}$ & & 1,2 & 1.030 & & 1,2 \\
\hline WO2 - locksmithing & $179 \times 10^{3}$ & & 1 & 0.998 & & 1 \\
\hline Company B & & $43 \times 10^{3}$ & & & 0.352 & \\
\hline WO3 - MIG/MAG welding II (manual) & $175 \times 10^{3}$ & & $1,2,3$ & 1.360 & & $1,2,3$ \\
\hline WO4 - operation of a welding machine (type A) & $128 \times 10^{3}$ & & 1,2 & 0.815 & & 1,2 \\
\hline WO5 - operation of a welding machine (type B) & $146 \times 10^{3}$ & & $1,2,3$ & 1.020 & & $1,2,3$ \\
\hline WO6 - operation of a spot welding machine & $96 \times 10^{3}$ & & 1,2 & 0.960 & & 1,2 \\
\hline Company C & & $51 \times 10^{3}$ & & & 0.383 & \\
\hline WO7 - MIG/MAG welding III (manual) & $83 \times 10^{3}$ & & 1,2 & 0.478 & & 1,2 \\
\hline WO8 - MIG/MAG welding IV (manual) & $165 \times 10^{3}$ & & 1 & 0.453 & & 1 \\
\hline
\end{tabular}

Technical risk controls: 1 - hall ventilation, 2 - local exhaust ventilation, 3 - portable fan.

Recommended occupational exposure limit for particle number concentration (1-100 nm) [28]: 20×103.

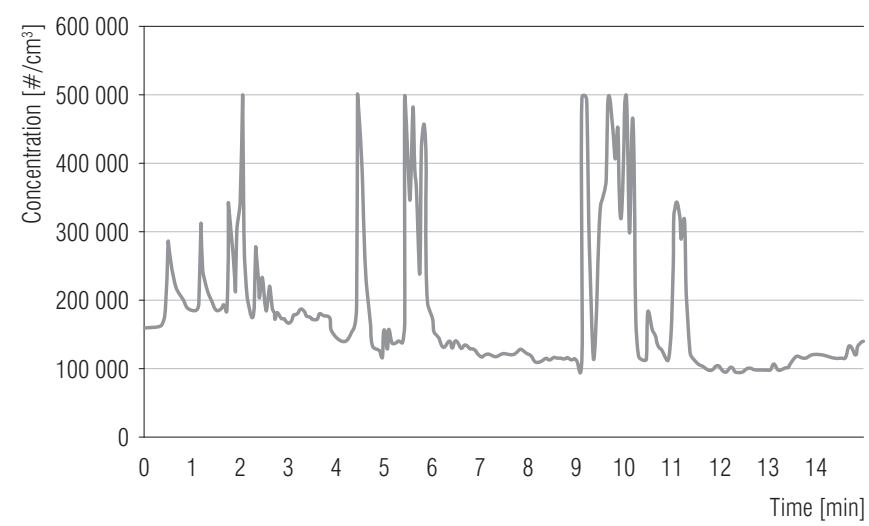

WO2 - locksmithing

Figure 2. Particle number concentration vs. time

Companies B and C were smoke-free environments (i.e., smoking was banned there). In Company A, however, the welder performing WO1 - MIG/MAG welding had smoked a cigarette before the start of the measurement. Cigarette smoke is a documented source of nanoparticles. Nevertheless, the cigarette had been smoked several meters from the place of the measurement. With regard to the size of the hall where the workplace was situated, and both local and hall ventilation, the potential effect can be neglected.

Welding operations with the highest concentrations (WO1-WO3) and the lowest concentrations of the total and $\mathrm{PM}_{1}$ particle mass fractions (WO7, WO8) did

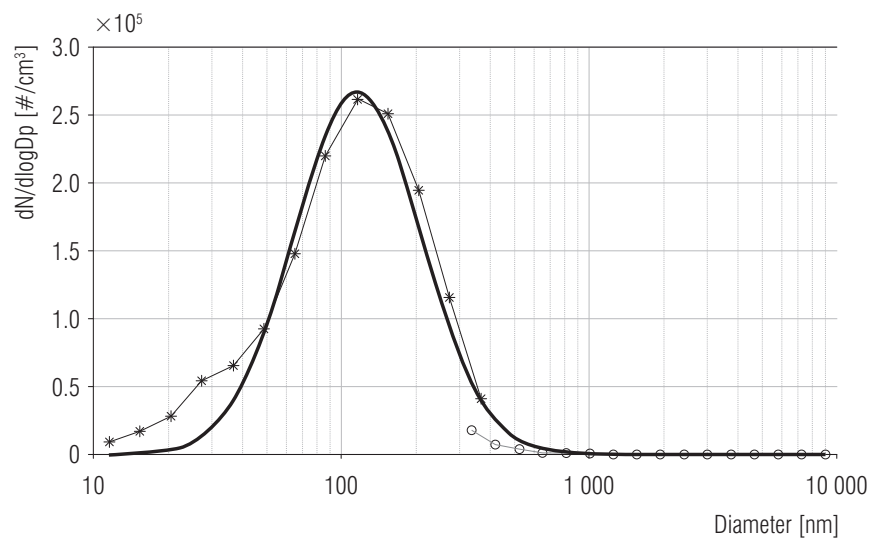

WO2 - locksmithing.

Figure 3. Particle size distribution

not entirely match with the welding operations with the highest (WO2, WO3, WO8) and the lowest (WO6, WO7) average particle number concentrations. In spite of the fact that the highest average total mass concentration was measured during WO3 - MIG/MAG welding II (manual), the corresponding average particle number concentration for WO3 was not the highest among all the concentrations obtained. The largest difference between the average particle number concentration and the average total particle mass concentration was observed for WO8 - MIG/MAG welding IV (manual). This could have been caused by the different size ranges of the measuring instruments used. While the P-TRAK 
Table 4. The average total mass fraction and $\mathrm{PM}_{1}$ fraction

\begin{tabular}{|c|c|c|c|}
\hline \multirow{2}{*}{$\begin{array}{l}\text { Welding operation } \\
\text { (WO) }\end{array}$} & \multicolumn{2}{|c|}{$\begin{array}{l}\text { Fraction } \\
{\left[\mathrm{mg} / \mathrm{m}^{3}\right]}\end{array}$} & \multirow{2}{*}{$\begin{array}{c}\mathrm{PM}_{1} / \mathrm{PM} \text { total ratio } \\
{[\%]}\end{array}$} \\
\hline & $\mathrm{PM}_{1}$ & total & \\
\hline WO2 - locksmithing & 0.998 & 1.220 & 82 \\
\hline WO3 - MIG/MAG welding II (manual) & 1.360 & 1.410 & 96 \\
\hline WO5 - operation of a welding machine (type B) & 1.020 & 1.070 & 95 \\
\hline WO6 - operation of a spot welding machine & 0.960 & 0.979 & 98 \\
\hline WO7 - MIG/MAG welding III (manual) & 0.478 & 0.546 & 88 \\
\hline WO8 - MIG/MAG welding IV (manual) & 0.453 & 0.629 & 72 \\
\hline
\end{tabular}

detects particles of $20-1000 \mathrm{~nm}$, the DustTrak detects all particles sized $>100 \mathrm{~nm}$.

Based on the available data from the measurements, there was no correlation between the workplace type (a workplace enclosed by welding screens, an open area), the applied technical risk controls, and the obtained concentrations. Similarly, partly automated welding operations (WO4-WO6) did not show distinctively higher or lower particle emissions than manual metal gas arc welding (WO1, WO7, WO8). With a larger number of technical risk controls and open workplaces, lower particle numbers and mass concentrations were expected. Moreover, higher particle number concentrations were not detected during manual welding operations in the companies with higher values of background particle concentrations.

These findings can be explained by several local conditions. Firstly, the duration of actual welding (the presence of an electric arc) during the 15-minute measuring interval was different for each welding operation. Secondly, the applied technical risk controls varied in their implementation in relation to efficacy and proximity to the aerosol source. Thirdly, the presence of other sources of aerosol emissions in the vicinity of the assessed workplaces, such as work activities carried out in the surrounding workplaces, the movement of motorized forklift trucks, the resuspension of dust particles, workplace cleanliness, and the frequency and form of cleaning, could have affected the results. The influence of these factors could not have been correctly evaluated over the relatively short 15-minute measuring intervals. Finally, due to the design of the measuring instruments and the arrangement of workplaces, it was not possible to perform aerosol monitoring directly in close proximity to the source of aerosol emissions or the worker's breathing zone. The measurements were, therefore, carried out depending on the local spatial conditions at different distances from the source of aerosol emissions and the worker's breathing zone. Despite these limitations, the measured values can be still viewed as indicative of occupational exposure.

The graphs of particle number concentrations vs. the time for each assessed welding operation consisted of peaks of various amplitudes. The emissions of particles appeared in short bursts, which can be explained by the discontinuous character of welding operations. In the case of manual welding, peaks appeared shortly after the formation of an electric arc. The time period between individual peaks (electric arcs) was associated with a decrease in the particle number concentrations. Welders changed welded spots, checked created joints or handled materials. A similar trend of peaks appearing shortly after the electric arc formation was observed during automated welding operations (WO4-WO6). Despite the periodical working rhythm of welding machines and their operators, the periodicity of the short bursts of nanoparticle emissions is diminishing in some segments of the graphs.

The graphs of the particle number size distribution of all welding operations resembled log-normal (Gauss) distribution with different modes and medians ranging $80-200 \mathrm{~nm}$, depending on the welding operation considered. The particle number size distribution of WO2 - Locksmithing is shown in Figure 3. In the case of WO7 - MIG/MAG welding III (manual) and WO8 MIG/MAG welding IV (manual), the most frequently occurring particle size ranged 64.9-86.6 nm. According to the International Commission on Radiological Protection semi-empirical regional compartment lung deposition model, about $30 \%$ of particles of the 
aforementioned size range (64.9-86.6 nm) deposit in the alveoli region, $10 \%$ in the bronchi region and $10 \%$ in the extrathoracic region [25]. When inhaled, these nanoparticles may cause respiratory tract diseases, e.g., asthma, bronchitis and chronic obstructive lung disease. The transition of nanoparticles from the alveoli into the cardiovascular system or the lymphatic system leads to the subsequent spread into various tissues and to cell damage [1].

The most common technical risk control at welding workplaces is hall ventilation combined with local exhaust ventilation. However, these risk controls were not installed specifically due to the presence of nanoparticles. According to the findings of available literature, the efficacy of technical risk controls for nano-sized particles generally reaches the same or higher value than for the total (inhalable) fraction. The average efficacy of local exhaust ventilation for nanoparticles sized $\leq 100 \mathrm{~nm}$ is said to range $90-97 \%$, and for hermetically sealed processes it is close to $100 \%$. A similar conclusion can be drawn about the use and effectiveness of personal protective equipment. The FFP3 type respirators reach an average efficacy of nearly 100\%, the FFP2 type respirators $98-100 \%$, and the FFP1 respirators $80-93 \%$ depending on the nanoparticle size [26].

The regulation of the occurrence of incidental nanoparticles at workplaces is mostly restricted to recommended OELs for specific nanomaterials or groups of nanomaterials by size or density. The recommended OELs were established by the National Institute for Occupational Safety and Health (NIOSH), the Occupational Safety and Health Administration (OSHA), the Institute for Occupational Safety and Health of the German Social Accident Insurance (IFA), and the British Standards Institution (BSI). Safe Work Australia (SWA) has suggested that the workplace exposure limit for iron and iron oxides nanoparticles should be equal to the workplace exposure limit for coarse particles $\left(5 \mathrm{mg} / \mathrm{m}^{3}\right)$ multiplied by 0.003 , i.e., $0.015 \mathrm{mg} / \mathrm{m}^{3}$ [27-29]. The IFA particle number OEL for metals and oxides was determined for particles in the size range of $1-100 \mathrm{~nm}$. The recommended OEL depends on the density of the substance. For biopersistent substances, metals and oxides with a density of $>6000 \mathrm{~kg} / \mathrm{m}^{3}$, the recommended OEL for the particle number concentration is $20000 \# / \mathrm{cm}^{3}$. For biopersistent substances with a density of $<6000 \mathrm{~kg} / \mathrm{m}^{3}$, the recommended OEL is $40000 \# / \mathrm{cm}^{3}$ [27]. The chemical analysis of the particles released during assessed welding operations was not performed.
In all welding operations, the welded material was structural steel. A density of $>6000 \mathrm{~kg} / \mathrm{m}^{3}$ (Fe) can, therefore, be assumed without further knowledge of the exact chemical composition. Some constituents of structural steel have lower density (C, Si, P, S). Their presence is, nevertheless, very minor. Therefore, the recommended preliminary limit of the particle number concentration, determined at $20000 \# / \mathrm{cm}^{3}$, was applied. The recommended limits by IFA are preliminary values defined as an increase over the background concentration levels. Therefore, the negative effect of nanoparticles on workers' health can still occur, even if the limit is not exceeded. Exceeding the limit should be taken as an impulse for applying (more) risk controls.

Different particle size ranges of the measurements (20-1000 nm) and the specified particle size range of OELs (1-100 nm) make an accurate comparison difficult. Nevertheless, based on the available particle number size distributions of individual measurements, it can be stated that the recommended OEL of $20000 \mathrm{H} / \mathrm{cm}^{3}$ was exceeded for the assessed welding operations. As regards the total particle mass concentrations, the OEL established by OSHA for welding fumes is $5 \mathrm{mg} / \mathrm{m}^{3}$ (8-hour time-weighted average for an 8-hour shift). This OEL was not exceeded for any of the considered welding operations. However, the limit should be applied on the workplace particle mass concentrations determined using the gravimetric method (a personal sampling pump drawing a known volume of air through a membrane filter). The particle mass concentrations were determined by the authors as averages of the values obtained by real-time sampling over a 15-minute period.

Due to the use of a different measurement method and a considerably shorter sampling time, the aforementioned conclusions about not exceeding the OEL values for the total particle mass concentration should be viewed as rough approximations. The indicative limit of $0.015 \mathrm{mg} / \mathrm{m}^{3}$ for nanoparticles cannot be applied due to different size ranges of the conducted measurements (the $\mathrm{PM}_{1}$ fraction) and the recommended OEL $(1-100 \mathrm{~nm})$, and the unknown particle number mass distributions.

According to the Personal Protective Equipment Methodology for Environments with a Risk of Occurrence of Nanoparticles, nanoparticles with a density of $>6000 \mathrm{~kg} / \mathrm{m}^{3}$, exceeding the particle number concentration of $40000 \# / \mathrm{cm}^{3}$, are rated in the highest risk grade $\mathrm{V}$. This risk grade also includes highly toxic, carcinogenic, mutagenic and asbestos-like substances. Thus, 
high nanoparticle number concentrations are, in terms of the risk, equivalent to substances with serious potential toxic effects. In terms of the length of exposure, the assessed welding operations rank among the highest hazard levels of risk grades III or IV. Based on the assigned risk grades and the recommended OELs, a negative impact on employees' health can be expected. In spite of all the applied risk controls at the welding workplaces, the use of personal respiratory protective equipment is in order. Respirators with FFP1 particle filters should provide sufficient protection from nanoparticle exposure, although the use of FFP2 or FFP3 particle filters is more recommended [30].

\section{CONCLUSIONS}

In compliance with the personally conducted measurements of particle numbers and mass concentrations during welding operations, it can be confirmed that there is a significant amount of incidental nanoparticles being released during work operations in the metal welding industry. Professions such as welders, locksmiths and welding machine operators involve exposure to nanoparticles, which may pose health risks. According to the authors' measurements of electric arc welding, the average particle number concentrations of particles in the size range of $20-1000 \mathrm{~nm}$ were between $83 \times 10^{3}-179 \times 10^{3} \# / \mathrm{cm}^{3}$. For all assessed welding operations, the recommended preliminary OEL for iron and iron oxides nanoparticles, determined at $20000 \# / \mathrm{cm}^{3}$, was exceeded $4-8$ times. Exposure risk controls are, therefore, recommended. Local exhaust ventilation in conjunction with workplace ventilation and personal respiratory protective equipment, such as respirators with FFP2 or FFP3 particle filters, should be sufficient in reducing personal exposure to nanoparticles.

\section{REFERENCES}

1. Skrehot PA, Rupova M. [Nanosafety]. 1st ed. Prague: Occupational Safety Research Institute; 2011. Czech.

2. Missauouoi WN, Arnold RD, Cummings BS. Toxicological status of nanoparticles: What we know and what we don't know. Chem Biol Interact. 2018;295:1-12, https://doi. org/10.1016/j.cbi.2018.07.015.

3. Sufian MM, Khattak JZK, Yousaf S, Rana MS. Safety issues associated with the use of nanoparticles in human body. Photodiagn Photodyn. 2017;19:67-72, https://doi. org/10.1016/j.pdpdt.2017.05.012.
4. ISO/TS 80004-1:2015 Nanotechnology - Vocabulary Part 1: Core terms. Geneva: International Organization for Standardization; 2015.

5. Commission Recommendation of 18 October 2011 on the definition of nanomaterial (2012/696/EU). Off J Eur Union. 2011;(696).

6. Amenta V, Aschberger K, Arena M, Bouwmeester H, Moniz FB, Brandhoff P, et al. Regulatory aspects of nanotechnology in the agri/feed/food sector in the EU and non-EU countries. Regul Toxicol Pharmacol. 2015;1(73): 463-76, https://doi.org/10.1016/j.yrtph.2015.06.016.

7. Klouda K, Frišhansova L, Sencik J. [Nanoparticles, Nanotechnologies and Nanoproducts and their Relation to Occupational Safety and Health]. J Safety Res Appl. 2016;9(special issue). Czech.

8. Dolez P. Nanoengineering: Global Approaches to Health and Safety Issues. 1st ed. London: Elsevier; 2015.

9. Viitanen AK, Uuksulainen S, Koivisto A, Hämeri K, Kauppinen T. A. Workplace measurements of ultrafine particles A literature review. Ann Work Expos Heal. 2017;61(7): 749-58, https://doi.org/10.1093/annweh/wxx049.

10. Li N, Georas S, Alexis N, Meng PF, Xia T, Williams MA, et al. A work group report on ultrafine particles (American Academy of Allergy, Asthma and Immunology): Why ambient ultrafine and engineered nanoparticles should receive special attention for possible adverse health outcomes in human subjects. J Allergy Clin Immunol. 2016;138(2): 386-96, https://doi.org/10.1016/j.jaci.2016.02.023.

11. Pavlovska I, Martinsone Z, Vanadzins I, Martinsone I, Seile A, Sudmalis P. Occupational exposure parameters for nanoparticulate matter toxicity: Metal versus wood processing. Process Saf Environ. 2016;102;230-7, https:// doi.org/10.1016/j.psep.2016.03.018.

12. Stebounova L, Gonzales-Pech NI, Park JH, Anthony TR, Grassian VH, Peters TM. Particle Concentrations in Occupational Settings Measured with Nanoparticle Respiratory Deposition (NRD) Sampler. Ann Work Expos Heal. 2018;62(6):699-710, https://doi.org/10.1093/annweh/ wxy033.

13. Mikołajczyk U, Bujak S, Szadkowska-Stańczyk I. [Worker Exposure to Ultrafine Particles During Carbon Black Treatment]. Med Pr. 2015;66(3):317-26, https://doi.org/ 10.13075/mp.5893.00185. Polish.

14. Vaquero C, Gelarza N, de Ipiña JLL, Gutierrez-Cañas C, Múgica I, Aragón G, et al. Occupational exposure to nano-TiO2 in the life cycle steps of new depollutant mortars used in construction. J Phys Conf Ser. 2015;617:1-7, https://doi.org/10.1088/1742-6596/617/1/012006.

15. Voliotis A, Bezantakos S, Giamarelou M, Valenti M, Kumar P, Biskos G. Nanoparticle emissions from tra- 
ditional pottery manufacturing. Environ Sci Process Impacts. 2014;16:1489-94, https://doi.org/10.1039/c3em0 0708j.

16. Cooper MR, West GH, Burelli LG, Dresser D, Griffin KN, Segrave AM, et al. Inhalation exposure during spray application and subsequent sanding of wood sealant containing zinc oxide nanoparticles. J Occup Environ Hyg. 2017;14(7):510-22, https://doi.org/10.1080/15459624.2017. 1296237.

17. Jensen ACØ, Levin M, Koivisto AJ, Kling KI, Saber AT, Koponen IK. Exposure Assessment of Particulate Matter from Abrasive Treatment of Carbon and Glass FiberReinforced Epoxy Composites - Two Case Studies. Aerosol Air Qual Res. 2015;5(15):1906-16, https://doi. org/10.4209/aaqr.2015.02.0086.

18. Alderighi M, Carrai P, Nobili C, Lopey F, Cuoma F, Ambrosone L. Nanoparticles from paper mills: A seasonal, numerical and morphological analysis. Colloids Surf. 2017;532:102-7, https://doi.org/10.1016/j.colsurfa. 2017.06.006.

19. Klouda K, Lach K, Bradka S, Cejpek J, Otahal P. Quantities and Distribution of Nano Metals and MicroParticles at Melting Furnace for Lead Wastes. J Chem Eng Mater Sci. 2014;2(5):106-18, https://doi.org/10.13189/ cme.2014.020503.

20. Klouda K, Sinay J, Cejpek J, Lach K. Identification of Nano- and Microparticle Aerosols Generated in Selected Operations. Acta Mech Slovaca. 2013;17(2):90-102, https://doi.org/10.21496/ams.2013.025.

21. Czech Statistical Office. [Statistical Yearbook of the Czech Republic]. 1st ed. Prague: Czech Statistical Office; 2018. Czech.

22. National Institute of Public Health. [Occupational diseases in the Czech Republic in 2017]. 1st ed. Prague: National Institute of Public Health; 2018. Czech.

23. EN 12341:2014. Ambient air - Standard gravimetric measurement method for the determination of the PM10 or
PM2,5 mass concentration of suspended particulate matter. Brussels: European Committee for Standardization; 2014.

24. EN 689:2019 + AC:2019. Workplace exposure Measurement of exposure by inhalation to chemical agents - Strategy for testing compliance with occupational exposure limit values. Brussels: European Committee for Standardization; 2019.

25. Majid H, Madl P, Khan A. Lung deposition predictions of airborne particles and the emergence of contemporary diseases Part-I. Health. 2011;2(2):51-9.

26. Goede H, Christopher-de Vries Y, Kuijpers E, Fransman W. A Review of Workplace Risk Management Measures for Nanomaterials to Mitigate Inhalation and Dermal Exposure. Ann Work Expos Heal. 2018;62(8):907-22, https://doi.org/10.1093/annweh/wxy032.

27. Assessing health and environmental risks of nanoparticles: current state of affairs in policy, science and areas of application, RIVM report 2014-0157. Bilthoven: National Institute for Public Health and the Environment; 2015.

28. National Institute for Occupational Safety and Health. Current Intelligence Bulletin 63: Occupational Exposure to Titanium Dioxide. Centers for Disease Control and Prevention [Internet]. Washington, D.C.: National Institute for Occupational Safety and Health; 2011 [cited 2019 Jul 6]. Available from: http://www.cdc.gov/niosh/ docs/2011-160/pdfs/2011-160.pdf.

29. US Department of Labor: Occupational Health and Safety Administration. OSHA FactSheet: Working Safely with Nanomaterials [Internet]. Washington: Occupational Health and Safety Administration; 2013 [cited 2019 Jul 6]. Available from: https://www.osha.gov/Publications/OSHA FS-3634.html.

30. Sencik J, Nechvatal M, Klouda K. [Certified methodology for providing personal protective equipment in environments at risk of nanoparticles]. Prague: Occupational Safety Research Institute; 2016. Czech.

This work is available in Open Access model and licensed under a Creative Commons Attribution-NonCommercial 3.0 Poland License - https://creativecommons.org/licenses/by-nc/3.0/pl/deed.en. 